\title{
Structure and significance of metaplastic nodules in the rectal mucosa
}

\author{
J. F. ARTHUR \\ From the Bland-Sutton Institute of Pathology, Middlesex Hospital Medical School, London
}

SYNOPSIS Small nodules are commonly seen in the rectal mucosa during sigmoidoscopy of patients over 40 years of age and are often noted in rectums excised for carcinoma.

There is little information in the literature on the pathology of these small nodules. There is evidence that there are various histological types which are possibly of different clinical significance.

This problem has been studied using a series of rectums removed surgically for carcinoma and a comparable series of rectums obtained at necropsy from subjects with no evidence of large bowel disease.

The incidence, distribution, and histological structure of nodules more than $1 \mathrm{~mm}$ in diameter has been studied.

The commonest histological types of lesion are found to be adenomas and metaplastic nodules.

The histological structure, mode of formation, natural history, and clinical significance of metaplastic nodules is considered in detail.

It is concluded that metaplastic nodules are a normal finding in the rectal mucosa of subjects over 40 years old. It is suggested that they represent an aging change in the mucosa.

They are easily distinguished histologically from adenomas and evidence is presented that they have no relation to them and are not liable to undergo malignant change.

Small nodules or sessile polyps in the rectal mucosa are commonly seen during the course of sigmoidoscopy. Microscopically some of these are recognizable as true adenomas but the majority have a different appearance and have been described as 'metaplastic polyps' (Morson, 1962; Arthur, 1962). Although the existence of these small nodules is widely known, there is little information about their detailed histological structure. The object of this paper is to determine the incidence of the different types of small rectal polyp with particular reference to metaplastic nodules and their histological structure.

\section{MATERIAL}

The material used in this investigation falls into three groups.

1 SURGICAL Forty-five radical resections of the rectum and anal canal for carcinoma.

2 POST-MORTEM MATERIALS SERIES I Fifty-one rectums removed at necropsy which were taken only from cases

Received for publication 13 March 1968. showing no macroscopic evidence of rectal disease. All subjects were over 40 years of age.

3 POST-MORTEM MATERIAL: SERIES II Twenty-five rectums which were removed at necropsy from cases showing no macroscopic evidence of rectal disease. All subjects were under 40 years of age.

\section{METHODS}

The whole mucosa of each specimen was studied by reflected and transmitted light and all mucosal nodules less than $5 \mathrm{~mm}$ in diameter were carefully examined. The number of nodules was counted, up to a maximum of 25 , and the results were recorded in groups as follows:

$\begin{array}{llll}\text { Group A } & \ldots & \ldots & 1-5 \text { nodules } \\ \text { Group B } & \ldots & \ldots & 6-15 \text { nodules } \\ \text { Group C } & \ldots & \ldots & 16-25 \text { nodulcs } \\ \text { Group D } & \ldots & \ldots & \text { More than } 25 \text { nodules }\end{array}$

The distribution of the nodules in the specimen was then examined. The incidence of nodules in three zones of the mucosa measured from the anal margin (zone 1, 0 to $5 \mathrm{~cm}$; zone 2,5 to $10 \mathrm{~cm}$; and zone 3,10 to $15 \mathrm{~cm}$ ) was recorded. Finally the macroscopic appearance of individual nodules was studied. After completion of the 
preliminary macroscopic examination, all lesions between 1 and $5 \mathrm{~mm}$ in diameter were removed for histological examination.

\section{RESULTS}

HISTOLOGICAL STRUCTURE OF MUCOSAL NODULES The lesions were classified into four groups: (1) metaplastic nodules; (2) adenomas; (3) nodules of lymphoid tissue; and (4) benign connective tissue tumours.

HISTOLOGICAL STRUCTURE OF METAPLASTIC NODULES These were found to have a very characteristic structure and were readily distinguished from adenomas (Fig. 1). The first striking difference is of general colour of staining. Adenomas are dark staining due to the increased density of nuclear material and increased cellularity, whereas metaplastic nodules are relatively pale and eosinophilic. In metaplastic nodules the mucosal glands are dilated and the varying height and infolding of the lining cells gives a serrated appearance to the epithelium very similar to that seen in the endometrium in the latter part of the secretory phase of the menstrual cycle.

The muscularis mucosae deep to the mucosal nodule breaks up into an open interlacing network of fibres, some of which extend upwards between the dilated tubules.

The epithelial cells of metaplastic nodules differ from those of an adenoma (Fig. 2). They are of columnar form but of variable height producing the serrations in the outline of the glands described above. The nuclei are large, rounded and vesicular, usually in the centre or basal half of the cell. The cells have a well marked striated border. These cells are very similar in appearance to the absorptive cells on the surface of the normal mucosa. Among these absorptive type cells are occasional goblet cells, identical in appearance and staining reaction with the goblet cells of the adjoining normal mucosa. The nuclei of these goblet cells are normal, and do not resemble the nuclei seen in goblet cells of an adenomatous polyp.

Chromaffin cells are uncommon in metaplastic nodules. Paneth cells have not been seen, in contrast with their frequent occurrence in adenomas (Lauren, 1961). The epithelial cells of a metaplastic nodule show little mitotic activity and there is marked contrast between the relatively inactive epithelium of these lesions and the numerous mitotic figures in the epithelium of adenomas.

Mode of formation of metaplastic nodules In the course of microscopical examination of strips of mucosa bearing macroscopically visible nodules, many examples of small lesions invisible to the

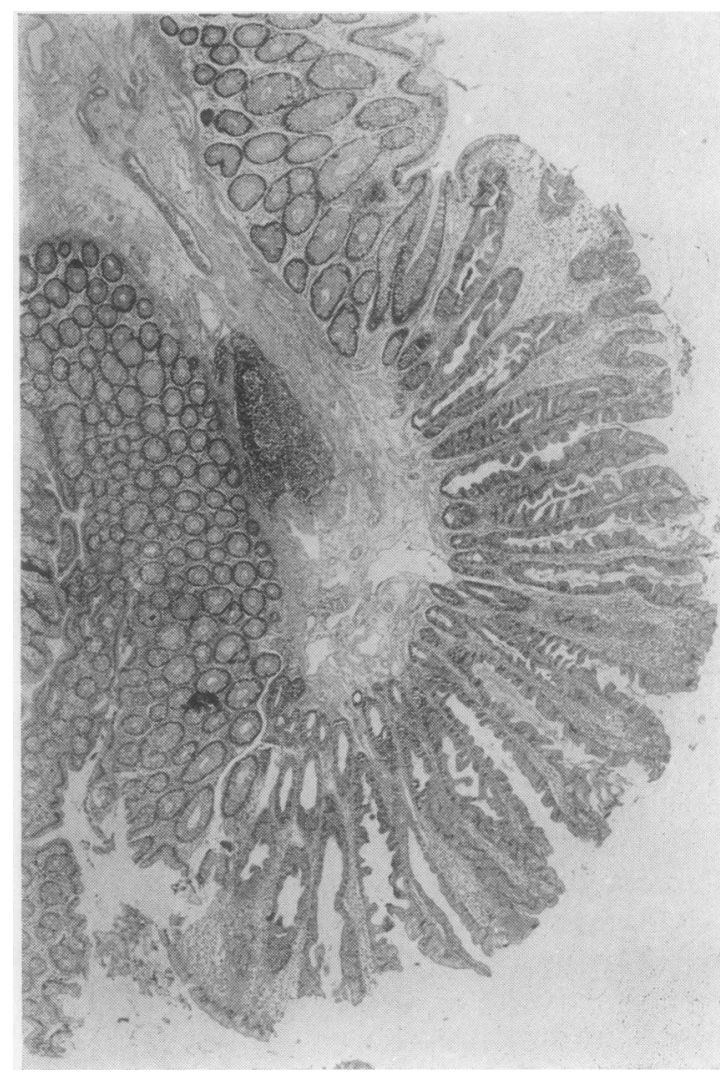

FIG. 1. Low-power view of a typical metaplastic nodule (haematoxylin and eosin $\times 30$ ).

naked eye were found. As a result of observations응 on these early lesions, the following sequence of $:$ events in the formation of a metaplastic nodule is suggested.

The earliest change observed was a dilatation of $₹$ the superficial parts of the mucosal glands and an 을 extension of the absorptive cells, normally lining the mucosa between the openings of the glands, into the dilated upper segments. This change was found with $\bar{N}$ no associated abnormality in the underlying mucosa or in the lamina propria (Fig. 3). In cases where the $N$ dilatation of glands extended halfway down the $\mathcal{N}$ thickness of the mucosa, changes began to appear in 0 the basal layers of the mucosa and in the muscularis 0 mucosae. The cells in the basal parts of the glands $\frac{\sim}{\Phi}$ become somewhat compressed in appearance and $\stackrel{\mathcal{P}}{+}$ the nuclear chromatin is condensed. The muscularis 7 mucosae breaks up into fasciculi and finally the $O$ dilatation of glands extends down to the deep limit $\stackrel{\Phi}{\overparen{D}}$ of the mucosa. In the early stages of formation of $\frac{\mathbb{Q}}{\mathbb{Q}}$ metaplastic nodules, the absorptive cells lining the dilated tubules are interspersed with fairly numerous 


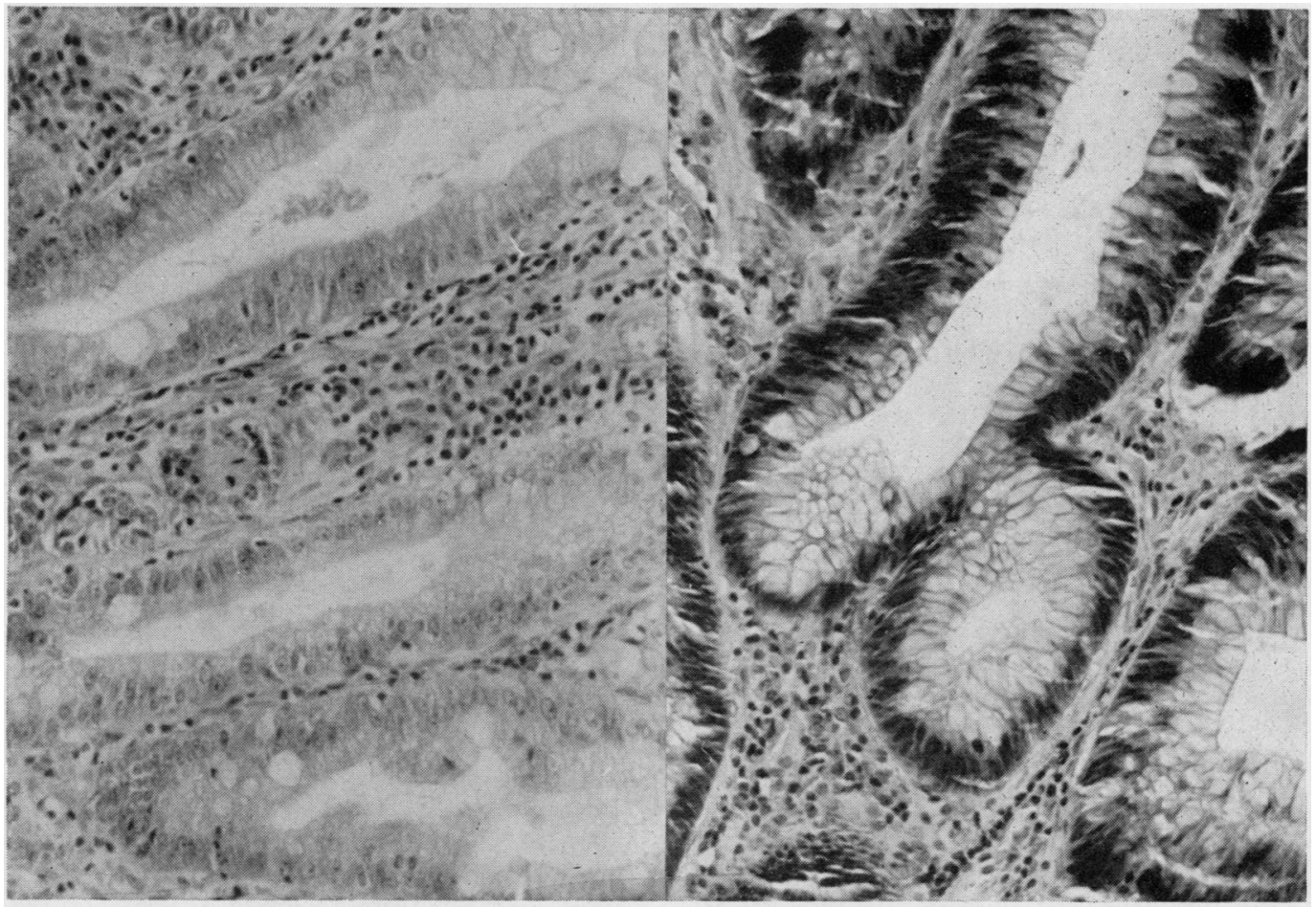

FIG. 2. High-power views of epithelium from a metaplastic nodule (left) and an adenoma (right) (haematoxylin and $\operatorname{eosin} \times 200$ ).

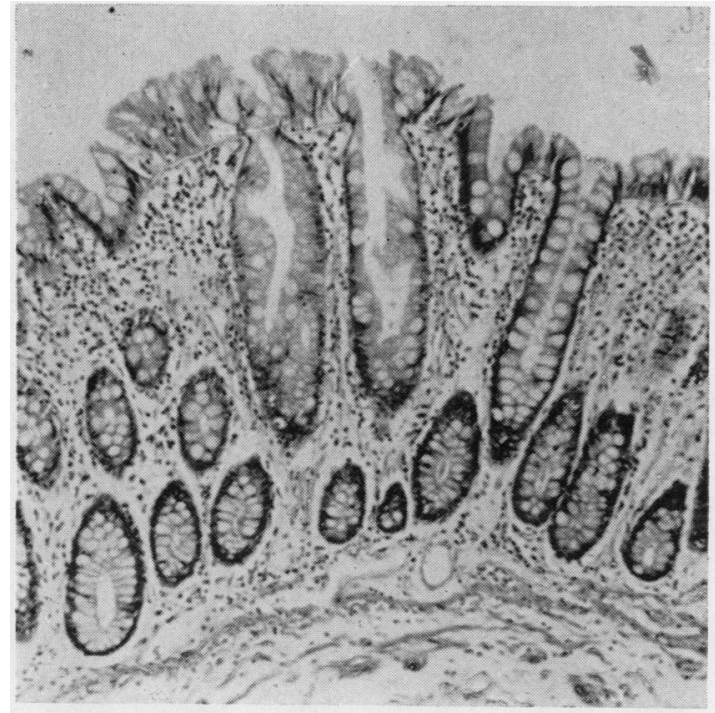

FIG. 3. Early stage in the formation of a metaplastic nodule (haematoxylin and eosin $\times 90$ ). goblet cells, but as the lesions age, the number of goblet cells decreases.

Lane and Lev (1963) pointed out that serial sectioning of small adenomas showed that they always involved the full thickness of the mucosa, although sections passing through the peripheral parts of the lesion might show adenomatous epithelium in the superficial part of the mucosa with normal epithelium underlying it. This has led to misconceptions about the true site of origin of adenomas.

Serial sections were cut of 10 metaplastic nodules to determine whether they involved the full thickness of the mucosa. The larger ones showed involvement of the full thickness of the mucosa at the centre of the lesion. Serial sections through the smaller ones, however, showed that the early lesion is confined to the superficial layers of the mucosa, thus confirming a fundamental difference between metaplastic nodules and adenomas.

Metaplastic nodules are almost always sessile lesions which show little tendency to become pedunculated. 


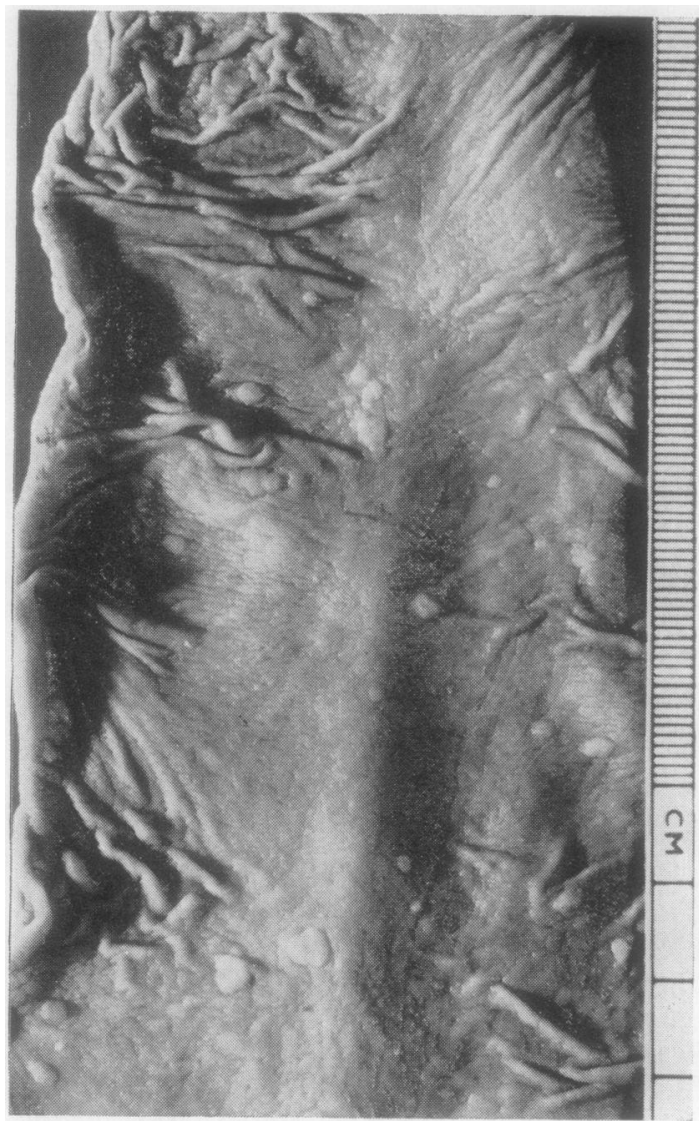

FIG. 4

FIG. 4. View of rectal mucosa showing numerous small nodules of varying shapes.

FIG. 5. Globular pedunculated type of mucosal nodule (variant 1). (Scale in millimetres.)

FIG. 6. Flat type of mucosal nodule (variant 2) blending with the mucosa at its periphery. (Scale in millimetres.)

FIG. 7. Flat type of mucosal nodule (variant 2) showing clear demarcation at the periphery. (Scale in millimetres.)

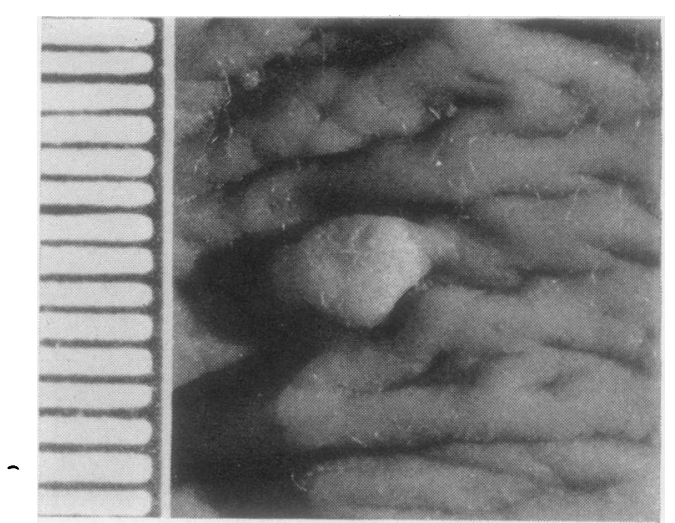

FIG. 5

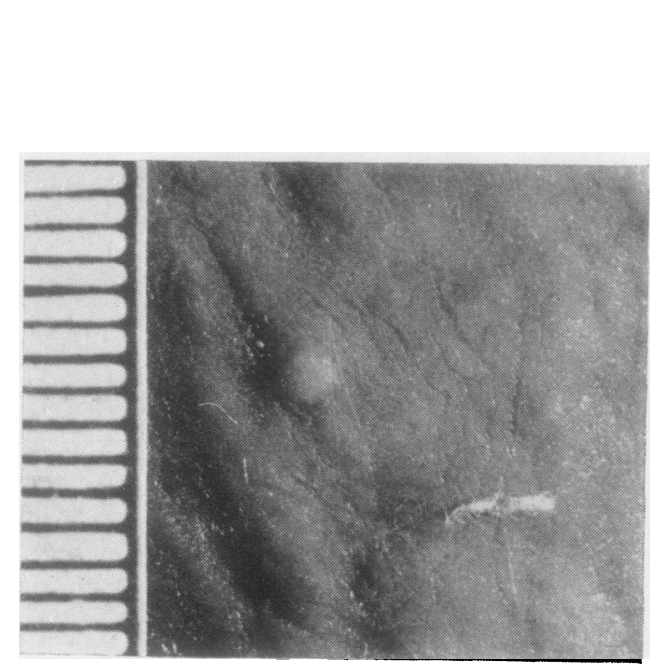

FIG. 6

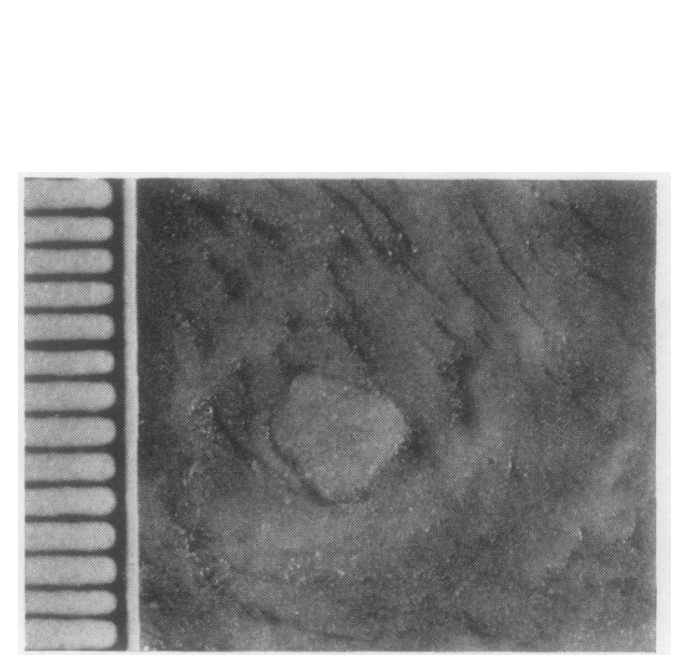

FIG. 7 
MACROSCOPIC APPEARANCES Small abnormalities in the rectal mucosa are often difficult to see and the first indication of a small nodule is a change in the surface colour of the mucosa; a paler spot about $0.5 \mathrm{~mm}$ in diameter is often visible. As the lesions become larger $(0.5$ to $1.0 \mathrm{~mm})$, they appear as dome or disc-shaped swellings projecting from the mucosa (Fig. 4). The macroscopic appearance of the nodules at this stage in their development is quite nonspecific and it has not been found possible to deduce their microscopic structure from it. Larger lesions ( 1 to $2 \mathrm{~mm}$ in diameter) begin to show different macroscopic characteristics. Three main variants can be demonstrated:

1 Solid nodules, globular in shape, with a smooth or slightly roughened surface, projecting markedly from the mucosa, sometimes even showing a short pedicle. The colour is similar to that of normal mucosa (Fig. 5).

2 Flat nodules with a broad base and a definitely papillary surface. Some of these lesions blend with the normal mucosa at their periphery and are not clearly demarcated. Others are set deeper in the mucosa and show a clear demarcation at the periphery. The appearance of this second type is similar to the circumvallate papillae on the dorsum of the tongue. The outline of this type of nodule may be round and regular or may show an irregular 'geographical' type of outline (Figs. 6 and 7). The colour is paler than that of normal mucosa.

3 Lesions which consist of a smooth elevation of the mucosa with a pale seed-like body visible deep to it.

The appearance of these three types of larger lesions does give some clue to their histological structure. Lesions of type 1 are usually small adenomas, lesions of type 2 metaplastic nodules, and lesions of type 3 lymphoid follicles.

FREQUENCY AND DISTRIBUTION OF LESIONS IN THE RECTUM

General frequency The overall incidence of nodules less than $5 \mathrm{~mm}$ in diameter in the three series is shown in Table I. Ninety-five per cent of the surgical series contained lesions as compared with $75 \%$ of the post-mortem series I (over 40 years of age) and $40 \%$ of the post-mortem series II (under 40 years of age). There is no significant difference in the sex incidence in any of the three series.

The number of nodules present in each specimen is recorded in Table II and Table III. Table III also shows the incidence of nodules in various age groups.

General distribution of lesions Each specimen was divided into three zones by standard measurements from the mucocutaneous junction in the
TABLE I

INCIDENCE OF MUCOSAL NODULES (1-5 MM DIAMETER) IN THE THREE SERIES OF CASES

\begin{tabular}{|c|c|c|c|c|}
\hline \multirow[t]{2}{*}{ Series } & \multicolumn{2}{|c|}{ Sex } & \multirow{2}{*}{$\begin{array}{l}\text { No. } \\
\text { of Cases } \\
\text { with Lesions }\end{array}$} & \multirow[t]{2}{*}{ Percentage } \\
\hline & $M$ & $F$ & & \\
\hline $\begin{array}{l}\text { Surgical } \\
\text { Total }\end{array}$ & 28 & 17 & $\begin{array}{l}27 \\
16 \\
43\end{array}$ & $\begin{array}{l}97 \\
94 \\
95\end{array}$ \\
\hline $\begin{array}{l}\text { Post-mortem series I } \\
\text { Total }\end{array}$ & 33 & 18 & $\begin{array}{l}27 \\
11 \\
38\end{array}$ & $\begin{array}{l}82 \\
61 \\
75\end{array}$ \\
\hline $\begin{array}{l}\text { Post-mortem series II } \\
\text { Total }\end{array}$ & 14 & 11 & $\begin{array}{r}5 \\
5 \\
10\end{array}$ & $\begin{array}{l}36 \\
45 \\
40\end{array}$ \\
\hline
\end{tabular}

TABLE II

FREQUENCY OF INCIDENCE OF MUCOSAL NODULES (1-5 MM DIAMETER) IN THE THREE SERIES OF CASES

$\begin{array}{llllll}\text { Series } & \text { No } & \text { Group A } & \text { Group B } & \text { Group C } & \text { Group D } \\ & \text { Lesions } & 1-5 & 6-15 & 16-25 & 25+\end{array}$

$\begin{array}{lrrrrr}\text { Surgical } & 2 & 15 & 15 & 5 & 8 \\ \text { Post-mortem I } & 13 & 20 & 16 & 1 & 1 \\ \text { Post-mortem II } & 15 & 8 & 2 & 0 & 0\end{array}$

TABLE III

INCIDENCE OF MUCOSAL NODULES IN AGE GROUPS IN THE THREE SERIES OF CASES

\begin{tabular}{lllllll} 
Age (yr) & $\begin{array}{l}\text { No. of } \\
\text { Cases }\end{array}$ & 0 & $\begin{array}{l}\text { Group A } \\
1-5\end{array}$ & $\begin{array}{l}\text { Group B } \\
6-15\end{array}$ & $\begin{array}{l}\text { Group C } \\
16-25\end{array}$ & $\begin{array}{l}\text { Group D } \\
25+\end{array}$ \\
\hline
\end{tabular}

\section{Surgical Series}

$\begin{array}{rrrrrrr}40-49 & 9 & 1 & 3 & 4 & 0 & 1 \\ 50-59 & 7 & 0 & 1 & 1 & 2 & 3 \\ 60-69 & 17 & 0 & 9 & 4 & 3 & 2 \\ 70-79 & 10 & 1 & 3 & 4 & 0 & 2 \\ 80-89 & 2 & 0 & 0 & 2 & 0 & 0\end{array}$

Post-mortem Series I

$\begin{array}{rrrrrrr}40-49 & 1 & 0 & 0 & 1 & 0 & 0 \\ 50-59 & 8 & 2 & 3 & 3 & 0 & 0 \\ 60-69 & 17 & 3 & 7 & 6 & 1 & 0 \\ 70-79 & 14 & 7 & 5 & 2 & 0 & 0 \\ 80-89 & 8 & 1 & 3 & 3 & 0 & 1 \\ 90-99 & 3 & 0 & 2 & 1 & 0 & 0\end{array}$

Post-mortem Series II

$\begin{array}{rrrrrrr}10-19 & 7 & 6 & 0 & 1 & 0 & 0 \\ 20-29 & 6 & 3 & 2 & 1 & 0 & 0 \\ 30-39 & 12 & 6 & 6 & 0 & 0 & 0\end{array}$

surgical specimens and from the lower end of the specimen (which normally coincided with the mucocutaneous junction) in the post-mortem specimens.

The number of lesions in each zone was counted and the results recorded in three groups as follows:

$$
\begin{array}{llll}
\text { Group 1 } & \ldots & \ldots & 0-5 \text { nodules } \\
\text { Group 2 } & \ldots & \ldots & 6-15 \text { nodules } \\
\text { Group 3 } & \ldots & \ldots & 16-25 \text { nodules (see Table IV) }
\end{array}
$$


TABLE IV

FREQUENCY OF MUCOSAL NODULES IN ZONES 1-3 IN THE THREE SERIES OF CASES

\begin{tabular}{lccc} 
& $\begin{array}{l}\text { Group 1 } \\
0-5\end{array}$ & $\begin{array}{l}\text { Group 2 } \\
6-15\end{array}$ & $\begin{array}{l}\text { Group 3 } \\
16-25\end{array}$ \\
\hline $\begin{array}{l}\text { Surgical Series } \\
\text { Zone 1 }\end{array}$ & 16 & 13 & 1 \\
Zone 2 & 11 & 17 & 11 \\
Zone 3 & 22 & 8 & 2 \\
Post-mortem Series I & & & \\
Zone 1 & 25 & 3 & 0 \\
Zone 2 & 23 & 11 & 1 \\
Zone 3 & 8 & 2 & 0 \\
Post-mortem Series H & & & \\
Zone 1 & 5 & 0 & 0 \\
Zone 2 & 7 & 1 & 0 \\
Zone 3 & 2 & 0 &
\end{tabular}

Distribution of lesions in relation to carcinomas in the surgical series In the surgical series, the distribution of nodules in relation to carcinomas was examined and the distances of the carcinomas from the mucocutaneous junction were recorded. Any apparent grouping of the lesions round a carcinoma was noted and the relative numbers of lesions above and below it were recorded. Twenty cases showed an equal distribution of lesions above and below the tumour; 13 cases showed most of the lesions above, and 10 , most of them below the tumour. Ten cases were considered to show grouping of lesions round a carcinoma.

RELATIVE FREQUENCY OF THE TWO MAIN HISTOLOGICAL TYPES OF LESION Details of the numbers of metaplastic nodules and adenomas found in each specimen are recorded in Tables V and VI.

Table $V$ shows the total number of the lesions found in each series and Table VI shows the number of cases in each series containing the various types of lesion.

In the surgical series, 37 cases $(82 \%)$ showed metaplastic nodules and $16(38 \%)$ adenomas. Postmortem series I showed 38 cases (75\%) with metaplastic nodules and nine $(18 \%)$ with adenomas. Post-mortem series II showed eight cases $(32 \%)$ with metaplastic nodules and no adenomas.

\section{TABLE V}

TOTAL NUMBERS OF THE DIFFERENT HISTOLOGICAL TYPES OF MUCOSAL NODULE FOUND IN THE THREE SERIES OF CASES

\begin{tabular}{llc} 
Series & $\begin{array}{l}\text { Metaplastic } \\
\text { Nodules }\end{array}$ & Adenomas \\
\hline $\begin{array}{c}\text { Surgical } \\
\text { (200 lesions) }\end{array}$ & 144 & 27 \\
$\begin{array}{c}\text { Post-mortem I } \\
\text { (138 lesions) }\end{array}$ & 107 & 10 \\
$\begin{array}{c}\text { Post-mortem II } \\
\text { (28 lesions) }\end{array}$ & 12 & 0
\end{tabular}

TABLE VI

HISTOLOGICAL TYPES OF MUCOSAL NODULES FOUND IN THE⿸尸 THREE SERIES OF CASES

\begin{tabular}{|c|c|c|c|c|c|}
\hline Age & $\begin{array}{l}\text { No. } \\
\text { of Cases }\end{array}$ & $\begin{array}{l}\text { No } \\
\text { Lesions }\end{array}$ & $\begin{array}{l}\text { Meta- } \\
\text { plastic } \\
\text { Nodules }\end{array}$ & Adenomas & $\begin{array}{l}\text { Both Types } \\
\text { Present }\end{array}$ \\
\hline \multicolumn{6}{|c|}{ Surgical Series } \\
\hline $40-49$ & 9 & 1 & 7 & 4 & 4 \\
\hline $50-59$ & 7 & $\mathbf{0}$ & 6 & 1 & 1 \\
\hline $60-69$ & 17 & $\mathbf{0}$ & 15 & 7 & 6 \\
\hline $70-79$ & 10 & 1 & 7 & 3 & 2 \\
\hline $80-89$ & 2 & $\mathbf{0}$ & 2 & 1 & 1 \\
\hline
\end{tabular}

\section{DISCUSSION}

Eighty-one of 96 rectums obtained from subjects ${ }^{\circ}$ over 40 years of age contained mucosal nodules less than $5 \mathrm{~mm}$ in diameter. Taking the surgical and post-s mortem specimens separately, $43(95 \%)$ of the surgical specimens and $38(75 \%)$ of the post-mortem specimens contained nodules.

The reported incidence of nodules and polyps in $\Rightarrow$ 'normal' rectums varies widely, owing to differences 3 in methods of observation and in the sizes of lesions? recorded. Atwater and Bargen (1945), using methodso similar to those used in this investigation, found nodules in $69 \%$ of a series of 241 necropsies. There. is no significant difference between this figure and? that obtained in the present series (difference $=6 \%$ $\mathrm{SE}=6 \cdot 7$ ). There are no comparable figures available for the incidence of small nodules in rectums containing a carcinoma.

The distribution of nodules within the rectum? was similar in the post-mortem and surgical specimens. The greatest density of lesions was found to N be in zone 2 (5 to $10 \mathrm{~cm}$ from the mucocutaneous junction). This observation is of importance in relation to the reported 'grouping' of small lesions $\omega$ round a carcinoma of the rectum (LockhartMummery and Dukes, 1928). Figures from St Markso Hospital records (Bussey, 1963) show that carcinoma is commonest in the middle third of the rectum ${ }^{\text {? }}$ (corresponding to zone 2 in this series) and this suggests that the grouping could be fortuitous, $\frac{O}{\mathbb{D}}$ occurring because carcinoma is commonest in the $\stackrel{\odot}{\odot}$ area where nodules reach their maximum density.

If the incidence of the two major types of mucosalo 
nodule (metaplastic nodules and minute adenomas) is considered separately, some interesting findings emerge.

In the surgical series of 45 cases, $37(82 \%)$ contained metaplastic nodules and $16(38 \%)$ contained adenomas. In the comparable post-mortem series of 51 cases, $38(75 \%)$ contained metaplastic nodules and nine $(18 \%)$ contained adenomas. It appears, therefore, that the incidence of metaplastic nodules in the two series is comparable (difference $=7 \%$, $\mathrm{SE}=8.3$ ) while the incidence of adenomas in the surgical series is significantly higher than in the postmortem series (difference $=20 \%, \mathrm{SE}=9.0$ ). The observation that $18 \%$ of normal persons over 40 years of age had adenomas is similar to the figure reported by Enquist (1957) for a comparable clinical series.

The incidence of adenomas in association with colonic cancer has been studied by many workers with rather variable results (Table VII). These figures give a total of 5,037 cases with a mean incidence figure for adenomas in association with carcinoma of $30 \%$. This is comparable with the figure for the surgical series of $38 \%$ (difference = $8 \%, \mathrm{SE}=7 \cdot 2$ ). It is concluded from the above data that small nodules having the histological structure of a metaplastic nodule are very common lesions in the rectums of persons over 40 years of age, and that they are equally common in normal controls and in those with carcinoma of the rectum. Nodules with the structure of adenomas are significantly more common in patients with carcinoma of the rectum than in normal controls.

\section{TABLE VII}

REPORTED INCIDENCE OF ADENOMAS IN ASSOCIATION WITH CARCINOMA OF THE RECTUM

$\begin{array}{llll}\text { Author } & \text { No. } & \text { Type } & \text { Percentage } \\ \text { of } & \text { of } & \text { with } \\ \text { Cases } & \text { Material } & \text { Adenoma }\end{array}$

$\begin{array}{lrlr}\text { Buser, Kirsner, and Palmer (1950) } & 478 & \text { Surgical } & 7 \cdot 9 \\ \text { David (1940) } & 128 & \text { Surgical } & 13 \cdot 0 \\ \text { Dukes (1926) } & 33 & \text { Surgical } & 75 \cdot 0 \\ \text { Helwig (1947) } & 25 & \text { Necropsy } & 52.0 \\ \text { Lahey and Swinton (1952) } & 3,000 & \text { Surgical } & 25 \cdot 0 \\ \text { Lawrence (1936) } & 67 & \text { Necropsy } & 27 \cdot 1 \\ \text { Mayo and Schlicke (1942) } & 334 & \text { Necropsy } & 34 \cdot 1 \\ \text { Mider (1946) } & 191 & \text { Necropsy } & 17 \cdot 0 \\ \text { Stewart (1931) } & 79 & \text { Necropsy } & 26 \cdot 6 \\ \text { Susman (1932) } & 34 & \text { Necropsy } & 44 \cdot 0 \\ \text { Swinton and Haug (1947) } & 195 & \text { Necropsy } & 25 \cdot 1 \\ \text { Thomas, Dockerty, and Waugh } & & & \\ \quad \text { (1948) } & 473 & \text { Surgical } & 19 \cdot 5\end{array}$

The first description of metaplastic nodules was given by Schmieden and Westhues (1927) who, in a histological study of rectal polyps, described three main types of lesion which are clearly recognizable as metaplastic nodules, villous papillomas, and solid adenomas. The first group they stated to be benign lesions which do not develop into carcinomas. The other two types were found to be precancerous. In a histological study of polyps in 300 patients with cancer of the large bowel, David (1940) said of polypoid lesions in general it is important to designate which lesions are true tumours and which are simple hyperplasias on a senile or inflammatory basis'. He described flat elevations of the mucosa the size of a millet seed as the commonest type of nodule and suggested that they were not related to adenomas. He compared them to 'senile hyperplasias' occurring in other sites, particularly in the skin (senile seborrhoiec warts). He also suggested that they might be areas of hyperplasia in response to inflammation in the colon; in support of this suggestion he pointed out that the lesions often occurred around an ulcerated malignant tumour and could also be seen to develop on the exposed mucosa of a colostomy stoma. His illustrations of hyperplastic lesions show histological appearances identical to those now described as metaplastic nodules. His conclusions as to the natural history of these small lesions were that they represented a response to inflammatory stimulation.

Scarborough and Klein (1948), in a study of 458 patients with polyps, found in the course of 10,000 sigmoidoscopies, divided the lesions into nonmalignant lesions $(5 \%)$, which included benign connective tissue tumours, granulomas, and lymphoid polyps, and premalignant lesions ( $95 \%)$, which included hyperplastic lesions as described by David (1940), and adenomas. No figures are given for the relative numbers of the various types of lesion. In commenting on hyperplastic nodules, they say that they are commonly found close to carcinomas of the rectum, but also state that they are commonly found in the rectums of elderly people who do not have carcinomas.

Morson (1962), discussing the histology of various types of intestinal polyp, concludes with a description of the 'metaplastic polyp'. He suggests the use of the term 'metaplastic polyp' to distinguish them from adenomas and to imply a change in the appearance of the mucosal epithelium.

Lane and Lev (1963), in a histological study of minute nodules in the rectal and colonic mucosa, confirmed the occurrence of two distinct types, which they described as adenomatous and hyperplastic nodules. They commented that the clarity of the histological difference between the two types of lesion had only rarely been noted in the very extensive literature on adenomas of the rectum and colon and concluded that the two lesions were not related to each other, and that hyperplastic nodules were by far the commoner. 
Wattenberg (1959), in a histochemical study of oxidative enzymes in large intestinal mucosa, described differences in the distribution of enzymes in normal mucosa, hyperplastic nodules, and adenomatous nodules. Culp, Dockerty, and Jackman (1966) studied 'satellite nodules' around carcinomas in surgical resection specimens; of 175 lesions, $114(65 \%)$ were less than $0.5 \mathrm{~cm}$ in diameter and of these $83(72 \%)$ were 'hyperplastic mucosal tags' and $29(25 \%)$ were adenomas. They equated hyperplastic mucosal tags with 'metaplastic polyps' as described by Morson (1962).

The occurrence of a distinctive histological type of nodule in the rectal mucosa, quite different in appearance from a small adenoma, is well established by the findings in this investigation and a survey of the literature. There is general agreement that small mucosal nodules of any kind are uncommon in young people, which is confirmed by the findings in the under-40-year-old post-mortem series II. Only occasional metaplastic nodules are seen before the age of 40 , but by the age of 60 they are present in $80 \%$ of cases.

The life history of metaplastic nodules is difficult to determine. There is evidence that they can regress and disappear. Enquist (1957) observed this in 79 cases with nodules varying from 0.5 to $4 \mathrm{~mm}$. For obvious reasons, the histological nature of these lesions was not determined, but the probability is that a large proportion were metaplastic nodules.

The evidence available suggests, therefore, that metaplastic nodules are to be found in the rectal mucosa of a high proportion of adults, and that the frequency of occurrence increases steadily with age. They grow slowly to a size of 1 to $5 \mathrm{~mm}$ in diameter and individual nodules may persist in the mucosa for long periods. They sometimes regress and disappear. Very occasionally they may grow to a larger size (up to $2 \mathrm{~cm}$ in diameter).

From a practical point of view, the relationship of metaplastic nodules to adenoma and carcinoma is the most important point to be clarified. Westhues (1934) considered that they were benign lesions not related to adenomas, and David (1940) concurred. On the other hand Lockhart-Mummery and Dukes (1928) and Scarborough and Klein (1948) considered them to be pre-malignant.

The presence of metaplastic nodules in the rectum of a patient over the age of 40 years can be accepted as a normal finding. The difficulty lies in distinguishing metaplastic lesions from adenomas. The distinction can only be made with certainty by biopsy of the lesions, but the following macroscopic differences may also be useful in making a clinical diagnosis:

SIZE Any lesion more than $5 \mathrm{~mm}$ in diameter is much more likely to be an adenoma than a meta $\stackrel{\text { ㅇ }}{-}$ plastic nodule.

SHAPE Metaplastic nodules are usually flat, disc like lesions while adenomas tend to be globular. An pedunculated lesion is more likely to be an adenomक than a metaplastic nodule.

COLOUR Metaplastic nodules are paler than the surrounding mucosa; adenomas tend to be the same colour or to appear congested.

Metaplastic nodules occur in the same age groups as adenomas, often in association with them. Thg pertinent question is whether they are a stage in thes development of adenomas, or whether they are a entirely separate and different lesion.

If metaplastic nodules were a stage in the develop ment of adenomas, one would expect to find transic్ tional forms fairly frequently. I have seen no cone vincing examples of transition from metaplastic. nodule to an adenoma and this observation is conz firmed by Lane and Lev (1963). If metaplastie nodules were precursors of adenomas, one woul\$ expect to find large numbers of metaplastic lesiong among the myriads of adenomas of all sizes present in the colon of patients with familial polyposis colico Lane and Lev (1963), in a detailed examination oథ̣ two colectomy specimens from cases of polyposisp failed to do so, and in a number of specimens o polyposis coli studied at St Mark's Hospital, it waรे found that the incidence of metaplastic nodules wa\& comparable to that found in normal persons of the same age (Morson, 1965). It is of some interest that Cole (1963), using radio-autographic methods, haş shown differences in the uptake of tritiated thymidine in the epithelium of metaplastic nodules and adenomas.

The histological differences between adenomas and metaplastic nodules are clear but the pathologica? nature of metaplastic nodules is a difficult problem? to determine. The main possibilities appear to be that they are benign neoplasms or hamartomas, $\mathrm{a}^{2}$ response to inflammation or trauma, or a degenera옥 tive change in the mucosa.

If metaplastic nodules were benign neoplasms on the rectal mucosa, one would expect them to shown considerable histological similarities to other lesions which are accepted as benign tumours, ie, adenomas. A variety of reasons have already been given forw thinking that they are in fact quite different. If they were hamartomas, one would expect to see them ato all periods of life-almost as commonly in children as in adults-and this is certainly not so. It has been? suggested that these lesions might be a response to inflammation, and David (1940) describes an inflam? matory infiltrate as an essential part of the histology. From my own findings only a small proportion of lesions show any significant inflammation. If theyo 
were inflammatory in nature, one would expect to see them in large numbers in cases of chronic inflammatory diseases of the colon, such as ulcerative colitis, Crohn's disease, and diverticular disease. Examination of surgical resection specimens from these diseases reveals occasional lesions, but with no greater frequency than would be expected in normal colons from patients of similar age.

The general opinion of most investigators is that metaplastic nodules represent degenerative changes in the mucosa. The increasing frequency of the lesions with advancing age and the absence of neoplastic qualities, as discussed in the last section, increases the probability that they are purely changes due to aging.

I would like to thank Dr Basil Morson and other members of the Research Department of St Mark's Hospital for their advice and encouragement. This work forms part of a thesis accepted for the Degree of Doctor of Medicine in the University of London.

\section{REFERENCES}

Arthur, J. F. (1962). Proc. roy. Soc. Med., 55, 703.
Atwater, J. S., and Bargen, J. A. (1945). Gastroenterology, 4, 395. Buser, J. W., Kirsner, J. B., and Palmer, W. L. (1950). Cancer (Philad.), $3,214$.

Bussey, H. J. R. (1963). Personal communication.

Cole, J. W. (1963). Personal communication.

Culp, C. E., Dockerty, M. B., and Jackman, R. J. (1966). Arch. Surg., 92,65 .

David, V. C. (1940). Ibid., 41, 257.

Dukes, C. (1926). Brit. J. Surg., 13, 720.

Enquist, I. F. (1957). Surgery, 42, 681.

Helwig, E. B. (1947). Surg. Gynec. Obstet., 84, 36.

Lahey, F. H., and Swinton, N. W. (1952). Lahey Clin. Bull., 7, 226.

Lane, N., and Lev, R. (1963). Cancer (Philad.), 16, 751.

Lauren, P. (1961). Acta path. microbiol. scand. suppl., 152.

Lawrence, J. C. (1936). Amer. J. Surg., 31, 499.

Lockhart-Mummery, J. P., and Dukes, C. (1928). Surg. Gynec. Obstet. 46, 591.

Mayo, C. W., and Schlicke, C. P. (1942). Ibid., 74, 83.

Mider, G. B. (1946). Surgery, $20,744$.

Morson, B. C. (1962). Dis. Colon Rect., 5, 337.

- (1965). Personal communication.

Scarborough, R. A., and Klein, R. R. (1948). Amer. J. Surg., 76, 723.

Schmieden, V., and Westhues, H. (1927). Dtsch. Z. Chir., 202, 1.

Stewart, M. J. (1931). Lancet, 2, 669.

Susman, W. (1932). J. Path. Bact., 35, 29.

Swinton, N. W., and Haug, A. D. (1947). Lahey Clin. Bull., 5, 84.

Thomas, J. F., Dockerty, M. B., and Waugh, J. M. (1948). Cancer (Philad.), 1, 564.

Wattenberg, L. W. (1959). Amer. J. Path., 35, 113.

Westhues, H. (1934). Die pathologisch-anatomischen Grundlagen der Chirugie des Rektumkarzinoms. Thieme, Leipzig. 